\title{
The dominant acetate degradation pathway/methanogenic composition in full-scale anaerobic digesters operating under different ammonia levels
}

\author{
I. A. Fotidis · D. Karakashev • I. Angelidaki
}

Received: 4 June 2013/Revised: 23 July 2013/Accepted: 22 October 2013/Published online: 7 November 2013

(C) Islamic Azad University (IAU) 2013

\begin{abstract}
Ammonia is a major environmental factor influencing biomethanation in full-scale anaerobic digesters. In this study, the effect of different ammonia levels on methanogenic pathways and methanogenic community composition of full-scale biogas plants was investigated. Eight full-scale digesters operating under different ammonia levels were sampled, and the residual biogas production was followed in fed-batch reactors. Acetate, labelled in the methyl group, was used to determine the methanogenic pathway by following the ${ }^{14} \mathrm{CH}_{4}$ and ${ }^{14} \mathrm{CO}_{2}$ production. Fluorescence in situ hybridisation was used to determine the methanogenic communities' composition. Results obtained clearly demonstrated that syntrophic acetate oxidation coupled with hydrogenotrophic methanogenesis was the dominant pathway in all digesters with high ammonia levels $\quad\left(2.8-4.57 \mathrm{~g} \mathrm{NH}_{4}^{+}-\mathrm{N} \mathrm{L}^{-1}\right)$, while acetoclastic methanogenic pathway dominated at low ammonia $\left(<1.21 \mathrm{~g} \mathrm{NH}_{4}^{+}-\mathrm{N} \mathrm{L}^{-1}\right)$. Thermophilic Methanomicrobiales spp. and mesophilic Methanobacteriales spp. were the most abundant methanogens at free ammonia concentrations above $0.44 \mathrm{~g} \mathrm{NH}_{3}-\mathrm{N} \mathrm{L}^{-1}$ and total ammonia concentrations above $2.8 \mathrm{~g} \mathrm{NH}_{4}^{+}-\mathrm{N} \mathrm{L}^{-1}$, respectively. Meanwhile, in anaerobic digesters with low ammonia $\left(<1.21 \mathrm{~g} \mathrm{NH}_{4}{ }^{+}-\mathrm{N} \mathrm{L}^{-1}\right)$ and free ammonia $\left(<0.07 \mathrm{~g} \mathrm{NH}_{3}-\right.$ $\mathrm{N} \mathrm{L}^{-1}$ ) levels, mesophilic and thermophilic Methanosaetaceae spp. were the most abundant methanogens.
\end{abstract}

Keywords Acetoclastic pathway - Ammonia toxicity · Anaerobic digestion · Hydrogenotrophic pathway

I. A. Fotidis · D. Karakashev · I. Angelidaki $(\bowtie)$ Department of Environmental Engineering, Technical University of Denmark, Building 113, 2800 Kongens Lyngby, Denmark e-mail: iria@env.dtu.dk

\section{Introduction}

Anaerobic digestion (AD) is a biological process which catabolises complex organic compounds (Minale and Worku 2013). AD is mediated by different microorganisms, mainly protozoa, fungi, bacteria and archaea, to produce biogas $\left(40-75 \% \mathrm{CH}_{4}\right.$ and $\left.25-60 \% \mathrm{CO}_{2}\right)$ from diverse organic substrates (Angelidaki et al. 2011). The archaea involved in the AD process are members of acetate utilising order Methanosarcinales (comprising two families: Methanosarcinaceae, versatile acetoclastic methanogens, and Methanosaetaceae, strictly acetoclastic methanogens) and strictly hydrogenotrophic Methanomicrobiales, Methanobacteriales, Methanococcales and Methanopyrales orders (Sarmiento et al. 2011). The complex organic substrates cannot be used by methanogens directly and must be catabolised by the other microorganisms mediating anaerobic digestion to substrates (e.g. acetate or $\mathrm{H}_{2}$ and $\mathrm{CO}_{2}$ ) suitable for methanogenesis. Hydrogenotrophic methanogens develop a syntrophic association with the syntrophic acetate-oxidising bacteria (SAOB). Acetate oxidation $\left(\mathrm{CH}_{3} \mathrm{COO}^{-}+4 \mathrm{H}_{2} \mathrm{O} \rightarrow\right.$ $2 \mathrm{HCO}_{3}^{-}+4 \mathrm{H}_{2}+\mathrm{H}^{+} \Delta \mathrm{G}^{\mathrm{o}^{\prime}}=+104.6 \mathrm{~kJ} \mathrm{~mol}^{-1}$ ) is a thermodynamically unfavourable bioreaction at standard conditions; however, coupling of the acetate oxidation with hydrogenotrophic methanogenesis $\left(4 \mathrm{H}_{2}+\mathrm{HCO}_{3}{ }^{-}+\right.$ $\left.\mathrm{H}^{+} \rightarrow \mathrm{CH}_{4}+3 \mathrm{H}_{2} \mathrm{O}\right)$ reduces the concentration of hydrogen and thereby decreases the $\Delta \mathrm{G}^{\mathrm{o}^{\prime}}\left(\Delta \mathrm{G}^{\mathrm{o}^{\prime}}=-135.6\right.$ $\left.\mathrm{kJ} \mathrm{mol}^{-1}\right)$, and the overall process becomes favourable. The interspecies hydrogen transfer between SAOB and hydrogenotrophic methanogens has been well described (Stams et al. 2006).

Ammonia (ammonium + free ammonia) is the major toxicant in full-scale anaerobic digesters, leading to 
suboptimal utilisation of the biogas potential of the feedstocks and causing economic losses to biogas production plants. High ammonia levels are often encountered in residues (e.g. pig, poultry and mink manures, slaughterhouse by-products), which otherwise would be highly suitable for biogas production. Anaerobic degradation of these residues can contribute to the increasing global need for more renewable energy sources and, consequently, lead to a future independence from the fossil fuels. Therefore, this ambitious goal requires an efficient industrial process for optimum biogas production, even from ammonia-rich substrates, as long as the ammonia toxicity problem is solved. Free ammonia, which increases concurrently with the temperature and $\mathrm{pH}$, has been identified as the main component causing methanogenesis inhibition (de Baere et al. 1984). Generally, for ammonia non-acclimatised methanogenic cultures, total ammonia and free ammonia concentrations over $3 \mathrm{~g} \mathrm{NH}_{4}^{+}-\mathrm{N} \mathrm{L}^{-1}$ and $0.15 \mathrm{~g} \mathrm{NH}_{3}$ $\mathrm{N} \mathrm{L}^{-1}$, respectively, are known to inhibit methanogenesis independently of temperature and $\mathrm{pH}$ levels (Yenigün and Demirel 2013).

The only realistic way today to counteract ammonia toxicity is to lower the temperature of the digester reducing the free ammonia levels (Nielsen and Angelidaki 2008a). However, this method can alleviate ammonia toxicity only to a limited range (Nielsen and Angelidaki 2008b). Other traditional physicochemical methods, based on addition of ammonium-binding ions (Kougias et al. 2013), increasing the $\mathrm{C} / \mathrm{N}$ ratio, dilution with water (Nielsen and Angelidaki 2008a) or striping of ammonia (Nakashimada et al. 2008), have not shown any practical applicability, and they are either unrealistic or too expensive.

When other important environmental factors (temperature, $\mathrm{pH}$ and volatile fatty acids (VFA)) are within optimum range, it is generally accepted that ammonia levels determine the dominant methanogenic pathway and the methanogenic community profile in laboratory-scale anaerobic reactors (Chen et al. 2008). The composition, the relative abundance and the interactions within the methanogenic community are critical for the performance of the anaerobic digester (Angelidaki et al. 2011). Among different microorganisms mediating $\mathrm{AD}$, methanogens are the most sensitive to ammonia inhibition (Kayhanian 1994). According to the literature, ammonia is mainly inhibiting the acetoclastic methanogenic (ACM) pathway, leading to VFA accumulation and suboptimal biogas production (Yenigün and Demirel 2013). Furthermore, syntrophic acetate oxidation followed by hydrogenotrophic methanogenesis (SAO-HM) metabolic pathway seems to be more robust to ammonia toxicity (Chen et al. 2008).

Up to now, research on how ammonia affects microbial composition and biochemical pathways has mainly focused on laboratory-scale biogas digesters. It is not clear how the methanogenic microbial communities respond to ammonia exposure in the complex environments of full-scale digesters. Therefore, it is necessary to obtain fundamental knowledge of the relations between ammonia and microbial ecology, which would assist the development of new microbiological methods to counteract ammonia inhibition. Thus, the aim of the present study was to investigate the effect of different ammonia levels on methanogenic pathways and methanogenic communities in full-scale anaerobic digesters. The work presented in this study was conducted in the Technical University of Denmark and was completed in November 2012.

\section{Materials and methods}

Inocula and media

A total of eight Danish centralised biogas plants (CBP) operating under different temperatures, hydraulic retention times, VFA and ammonia levels were sampled (Table 1). All digesters were fully mixed tank reactors. The selection of those plants was based on previous studies (Karakashev et al. 2005; Karakashev et al. 2006) in order to define representative groups of reactors within desired range of ammonia concentrations (low: $<1.5 \mathrm{~g} \mathrm{NH}_{4}{ }^{+}-\mathrm{N} \mathrm{L}^{-1}$, medium: 1.5-2.8 $\mathrm{g} \mathrm{NH}_{4}{ }^{+}-\mathrm{N} \mathrm{L}^{-1}$ and high: $>2.8 \mathrm{~g} \mathrm{NH}_{4}^{+}-\mathrm{N} \mathrm{L}^{-1}$ ), primary feedstocks and temperatures.

The feedstock for six of the digesters (Nysted, Hashøj, Vegger, Studsgård, Snertinge and Lemvig) consisted of 70-90 \% animal manure and 10-30 \% organic waste from abattoirs or food industries. Two CBP (Lundtofte and Hillerød) were fed with primary and secondary WWTP sludge. The samples were collected from the effluent lines of the digesters and immediately transferred in 2-L polyvinyl chloride containers closed with one-way valve on the lid to release overpressure created by residual biogas production. The sealed containers were transported to the laboratory within $24 \mathrm{~h}$.

\section{Experimental setup}

In the experiments, $118-\mathrm{mL}$ fed-batch reactor vessels (serum vial type) were used. $40 \mathrm{~mL}$ inocula were dispensed anaerobically under a $\mathrm{N}_{2} / \mathrm{CO}_{2}(80 / 20 \%)$ headspace in fedbatch reactors which were closed with butyl rubber stoppers, sealed with aluminium caps and incubated at respective temperatures where the inocula were taken from (Table 1). All experiments were conducted in triplicates. In order to follow the residual biogas production of the 
Table 1 Full-scale digesters working conditions and characteristics of the digesters' content

\begin{tabular}{|c|c|c|c|c|c|c|c|}
\hline Plant & $\begin{array}{l}\text { Operating } \\
\text { Temp. } \pm \mathrm{SD} \\
\left({ }^{\circ} \mathrm{C}\right)^{\mathrm{b}}\end{array}$ & $\begin{array}{l}\text { Primary } \\
\text { feedstock }\end{array}$ & $\mathrm{pH} \pm \mathrm{SD}^{\mathrm{c}}$ & $\begin{array}{l}\mathrm{VFA} \pm \mathrm{SD} \\
\left(\mathrm{g} \mathrm{HAc} \mathrm{L}^{-1}\right)^{\mathrm{c}}\end{array}$ & $\begin{array}{l}\mathrm{TNK}^{\mathrm{d}} \pm \mathrm{SD} \\
\left(\mathrm{g} \mathrm{N} \mathrm{L}^{-1}\right)^{\mathrm{c}}\end{array}$ & $\begin{array}{l}\text { Total } \\
\text { ammonia } \pm \mathrm{SD} \\
\left(\mathrm{g} \mathrm{NH}_{4}^{+}-\mathrm{N} \mathrm{L}^{-1}\right)^{\mathrm{c}}\end{array}$ & $\begin{array}{l}\text { Free ammonia }{ }^{\mathrm{e}} \pm \mathrm{SD} \\
\left(\mathrm{g} \mathrm{NH}_{3}-\mathrm{N} \mathrm{L}^{-1}\right)^{\mathrm{c}}\end{array}$ \\
\hline Nysted & $38 \pm 1$ & Pig slurry & $7.86 \pm 0.02$ & $0.56 \pm 0.08$ & $4.18 \pm 0.04$ & $2.93 \pm 0.11$ & $0.25 \pm 0.01$ \\
\hline Hashøj & $37 \pm 1$ & Cattle and pig slurry & $7.92 \pm 0.04$ & $0.80 \pm 0.05$ & $5.81 \pm 0.13$ & $4.57 \pm 0.15$ & $0.44 \pm 0.01$ \\
\hline Lundtofte $^{\mathrm{a}}$ & $35 \pm 1$ & $\begin{array}{l}\text { Primary and } \\
\text { biological sludge }\end{array}$ & $7.48 \pm 0.03$ & $0.03 \pm 0.01$ & $2.29 \pm 0.04$ & $1.21 \pm 0.06$ & $0.05 \pm 0.01$ \\
\hline Vegger & $55 \pm 1$ & Cattle manure & $7.99 \pm 0.01$ & $1.12 \pm 0.03$ & $3.03 \pm 0.01$ & $2.03 \pm 0.08$ & $0.51 \pm 0.02$ \\
\hline Studsgård & $52 \pm 1$ & Cattle and pig slurry & $7.96 \pm 0.04$ & $0.94 \pm 0.07$ & $3,72 \pm 0.09$ & $2.04 \pm 0.05$ & $0.48 \pm 0.01$ \\
\hline Snertinge & $52.5 \pm 1$ & Cattle and pig slurry & $7.77 \pm 0.04$ & $1.71 \pm 0.06$ & $3.07 \pm 0.08$ & $2.26 \pm 0.11$ & $0.37 \pm 0.02$ \\
\hline Lemvig & $52.5 \pm 1$ & $\begin{array}{l}\text { Cattle, pig and } \\
\text { poultry slurry }\end{array}$ & $7.86 \pm 0.03$ & $1.83 \pm 0.02$ & $3.24 \pm 0.12$ & $2.44 \pm 0.08$ & $0.48 \pm 0.02$ \\
\hline Hillerød $^{\mathrm{a}}$ & $55 \pm 1$ & $\begin{array}{l}\text { Primary and } \\
\text { biological sludge }\end{array}$ & $7.4 \pm 0.02$ & $0.02 \pm 0.01$ & $1.54 \pm 0.01$ & $0.90 \pm 0.08$ & $0.07 \pm 0.01$ \\
\hline
\end{tabular}

\footnotetext{
${ }^{a}$ Wastewater treatment plants

b Temperature deviation (SD)

c Data are mean values $(n=3) \pm$ standard deviation (SD)

d Total Kjeldahl nitrogen

${ }^{\text {e }}$ Calculated according to Eq. 1
}

inocula and define the methanogenic pathway, the following fed-batch reactors were included: a) three fed-batch reactors with inoculum only for estimation of residual methane production and $\mathrm{b}$ ) three fed-batch reactors containing $47.58 \pm 5.49 \mathrm{KBq} \mathrm{L}^{-1}$ or $1.3 \pm 0.15 \mu \mathrm{g} \mathrm{L}^{-1}$ $\left[2-{ }^{14} \mathrm{C}\right]$ sodium acetate (Amersham Pharmacia Biotech, England) for methanogenic pathway identification (calculation of ${ }^{14} \mathrm{CO}_{2} /{ }^{14} \mathrm{CH}_{4}$ ratio).

Analytical methods

Methane production was determined using gas chromatograph (Shimadzu GC-8A, Tokyo, Japan) equipped with a glass column $(2 \mathrm{~m}, 5 \mathrm{~mm}$ OD, $2.6 \mathrm{~mm}$ ID) packed with Porapak Q 80/100 mesh (Supelco, Bellefonte, PA, USA) and with a flame ionisation detector (FID). The oven temperature was $70{ }^{\circ} \mathrm{C}$, and nitrogen was the carrier gas. Total nitrogen (TKN), total ammonia and $\mathrm{pH}$ were determined according to APHA's standard methods (APHA 2005). VFA were determined using gas chromatograph (HP 5890 series II) equipped with a flame ionisation detector (FID) and an HP-FFAP column as described previously (Kotsopoulos et al. 2009). The $\mathrm{pH}$ of the fed-batch reactors was measured before and after the experimental period with PHM99 LAB pH meter (Radiometer $\left.^{\mathrm{TM}}\right)$. All the analyses were carried out in triplicate, and the average values are presented with the corresponding standard deviations calculated from the analyses. All the results are given under standard temperature and pressure conditions.
FISH analyses

FISH was used to identify the methanogenic microbial populations as described before by Hugenholtz (2002). Samples for FISH analyses were taken before the experiments. The probes used along with their target domains, orders or families are presented in Table 2. All probes were used at optimal stringency with 0-50 \% formamide as described in previous work (Fotidis et al. 2013b). ARC915 was used to identify all members of the Archaea domain, and EUB338 and EUB338 + were used for all bacterial members. $0.35 \mathrm{mg} \mathrm{L}^{-1}$ of $4^{\prime}, 6^{\prime}$-diamidino-2-phenylindole (DAPI) in Milli-Q water was used for total cell identification. Following hybridisation, slides were visualised with an epifluorescence microscope (Olympus BX60, Olympus Corporation of the Americas). Microphotographs were taken with a Leica DFC320 camera (Leica Microsystems Imaging Solutions Ltd, United Kingdom). Excitation channels were $353 \mathrm{~nm}, 488 \mathrm{~nm}$ and $545 \mathrm{~nm}$ for DAPI (blue emission filter), 6-FAM fluorescein amidite (green emission filter) and $\mathrm{Cy} 3$ fluorochrome (red emission filter), respectively. The determination of the dominant methanogenic populations was based on approximately 20 microscope fields examined using $63 \times 1.4$-fold objective lenses, expressing approximately 2,000-10,000 individual cells. Dominant and non-dominant methanogenic groups represented 50-100 and $1-49 \%$ of all Archaea members (positive for ARC915), respectively. Finally, hydrogenotrophic 
Table 2 Oligonucleotide probes used for the microbe population identification

\begin{tabular}{lllll}
\hline Probe & Phylogenetic group & Functional group & Probe sequence $\left(5^{\prime}-3^{\prime}\right)^{\mathbf{b}}$ & Reference \\
\hline ARC915 & Archaea & Mainly meth. ${ }^{\text {a }}$ & GTGCTCCCCCGCCAATTCCT & Stahl and Amann (1991) \\
MB1174 & Methanobacteriales & Hydrogenotrophic meth. & TACCGTCGTCCACTCCTTCCTC & Sekiguchi et al. (1999) \\
MC1109 & Methanococcales & Hydrogenotrophic meth. & GCAACATAGGGCACGGGTCT & Raskin et al. (1994) \\
MG1200 & Methanomicrobiales & Hydrogenotrophic meth. & CGGATAATTCGGGGCATGCTG & Sekiguchi et al. (1999) \\
MS1414 & Methanosarcinaceae & Acetoclastic meth. (also hydrogen) & CTCACCCATACCTCACTCGGG & Sekiguchi et al. (1999) \\
MSMX860 & Methanosarcinales & Acetoclastic meth. (also hydrogen) & GGCTCGCTTCACGGC TTCCCT' & Raskin et al. (1994) \\
MX825 & Methanosaetaceae & Acetoclastic meth. & TCGCACCGTGGCCGACACCTAGC & Raskin et al. (1994) \\
\hline
\end{tabular}

${ }^{a}$ Meth. methanogenic

${ }^{\mathrm{b}} \mathrm{W}, \mathrm{A}+\mathrm{T}$ mixed base

Methanopyrales spp. (Shima et al. 1998) has a hyperthermophilic (optimum temperature $98^{\circ} \mathrm{C}$ ) member species and was not considered further in this study.

Radioisotopic analyses

As it has been demonstrated before (Fotidis et al. 2013b), methanogenic pathway can be determined by measuring the production of ${ }^{14} \mathrm{CH}_{4}$ and ${ }^{14} \mathrm{CO}_{2}$ from acetate labelled in the methyl group $(\mathrm{C}-2)$. When SAO-HM is the dominant methanogenic pathway, the methyl group of the $\left[2-{ }^{14} \mathrm{C}\right]$ acetate is converted to ${ }^{14} \mathrm{CO}_{2}$. Combined with the fact that the pool of labelled carbon dioxide $\left({ }^{14} \mathrm{CO}_{2}\right)$ in $\mathrm{AD}$ is much lower than the pool of unlabelled ${ }^{12} \mathrm{CO}_{2}$, the hydrogenotrophic methanogenesis will only convert a small part of ${ }^{14} \mathrm{CO}_{2}$ molecules to ${ }^{14} \mathrm{CH}_{4}$. On contrary, when ACM is the dominant methanogenic pathway, ${ }^{14} \mathrm{C}$ carbon derived from the methyl group of the $\left[2-{ }^{14} \mathrm{C}\right]$ acetate goes to ${ }^{14} \mathrm{CH}_{4}$. Therefore, the concentration of ${ }^{14} \mathrm{CH}_{4}$ in the gas phase will be much higher compared to the concentration of ${ }^{14} \mathrm{CO}_{2}$ formed during the oxidation of $\left[2-{ }^{14} \mathrm{C}\right]$ acetate. It is generally assumed that when ${ }^{14} \mathrm{CO}_{2} /{ }^{14} \mathrm{CH}_{4}<1$, the dominant pathway is ACM, while when ${ }^{14} \mathrm{CO}_{2} /{ }^{14} \mathrm{CH}_{4}>1$, SAO-HM is the dominant pathway. In the current experiment, after the residual biogas production ceased, fed-batch reactors containing $\left[2-{ }^{14} \mathrm{C}\right]$ acetate were acidified (final $\mathrm{pH}=0.95 \pm 0.1$ ) with $7.2 \mathrm{M} \mathrm{HCl}$. Thus, dissolved $\mathrm{H}^{14} \mathrm{CO}_{3}{ }^{-}$converted to ${ }^{14} \mathrm{CO}_{2}$ and trapped with a $\mathrm{CO}_{2}$ absorber for liquid scintillation counting $\left(\right.$ Carbosorb $^{\mathrm{R}}-\mathrm{E}$; PerkinElmer Company). The ${ }^{14} \mathrm{CH}_{4}$ was combusted to ${ }^{14} \mathrm{CO}_{2}$ in a tube furnace $\left(\geq 800{ }^{\circ} \mathrm{C}\right)$ and the ${ }^{14} \mathrm{CO}_{2}$ produced trapped also in Carbosorb ${ }^{\mathrm{R}}$-E. Supernatant of the liquid part of the fed-batch reactors was mixed with tap water and scintillation liquid (Ultima Gold ${ }^{\mathrm{TM}} \mathrm{XR}$, PerkinElmer Company), to measure the residual $\left[2-{ }^{14} \mathrm{C}\right]$ acetate radioactivity. All radioactivity measurements were taken in triplicates using a liquid scintillation counter (Tri-Carb
1600; PerkinElmer Company), according to Fotidis et al. (2013b).

Calculations

\section{Free ammonia}

Free ammonia concentrations were calculated from the equilibrium of Eq. (1) (Fotidis et al. 2013b):

$\left[\mathrm{NH}_{3}\right]=\frac{\left[\mathrm{NH}_{3}+\mathrm{NH}_{4}\right]}{1+\frac{10^{-\mathrm{pH}}}{K_{\alpha}}}$

where $\left[\mathrm{NH}_{3}\right]$ and $\left[\mathrm{NH}_{3}+\mathrm{NH}_{4}^{+}\right]$are the free and total ammonia concentrations, respectively. $K_{a}$ is the dissociation constant, with values $1.13 \times 10^{-9}, 1.28 \times 10^{-9}$, $1.29 \times 10^{-9}, 3.27 \times 10^{-9}, 3.37 \times 10^{-9}$ and $3.89 \times 10^{-9}$ for $35,37,38,52,52.5$ and $55^{\circ} \mathrm{C}$, respectively, calculated as described previously (Hafner et al. 2006) with the use of the corresponding $\mathrm{pH}$ values (Table 1 ).

\section{Growth rate}

The maximum specific growth rate of the mixed methanogenic cultures $\left(\mu_{\max }\right)$ was calculated from the slope of the linear part of the graph of residual methane production (natural logarithm) versus time as described before (Gray et al. 2009).

\section{Statistical analysis}

The GraphPad Prism program (Graphpad Software, Inc., San Diego, California) was used to perform statistical analysis. The Student's $t$ test for statistically significant difference $(P<0.05)$ was used to compare the specific growth rates of the different methanogenic populations, and all values were the mean of three independent replicates $(n=3) \pm$ standard deviation (SD). 


\section{Results and discussion}

Maximum specific growth rates

All eight fed-batch reactors produced methane without any lag phase for 18-22 days before they enter into the "stationary phase", demonstrating a normal AD process (data not shown). The current results did not establish a clear correlation between $\mu_{\max }$ and ammonia levels (Fig. 1) of the full-scale digesters tested. The highest $\mu_{\max }$ (statistically significant difference, $P<0.05)$ was found at high ammonia levels $\left(2.93 \mathrm{~g} \mathrm{NH}_{4}{ }^{+}-\mathrm{N} \mathrm{L}^{-1}\right)$, and the lowest $\mu_{\max }$ (statistically significant difference, $P<0.05$ ) was found at medium ammonia levels $\left(2.26 \mathrm{~g} \mathrm{NH}_{4}{ }^{+}-\mathrm{N} \mathrm{L}^{-1}\right.$ and $2.44 \mathrm{~g}$ $\mathrm{NH}_{4}{ }^{+}-\mathrm{N} \mathrm{L}^{-1}$ (statistically no significant difference, $P>0.05)$ ). In all the other ammonia concentrations, $\mu_{\max }$ varied between 0.050 and $0.061 \mathrm{~h}^{-1}$ (Fig. 1). This indicates that some degree of acclimatisation of the corresponding methanogenic cultures to the different ammonia levels in the digesters had occurred through long-term exposure (Rajagopal et al. 2013). Nevertheless, mixed mesophilic methanogenic cultures digesting animal manure at low ammonia and low free ammonia levels were previously reported to have $\mu_{\max }$ of $0.1 \mathrm{~h}^{-1}$ (Koster and Koomen 1988), which is significantly higher compared to the growth rates found in the current study. Therefore, it can be concluded that all the digesters treating manure, tested in the current experiment, were operating under "inhibitory steady state" affected by the ammonia and/or free ammonia inhibitory levels (Nielsen and Angelidaki 2008b).

Low $\mu_{\max }$ in digesters with high VFA levels (above $1.5 \mathrm{~g} \mathrm{HAc} \mathrm{L}^{-1}$, in cases of Lemvig and Snertinge) can be

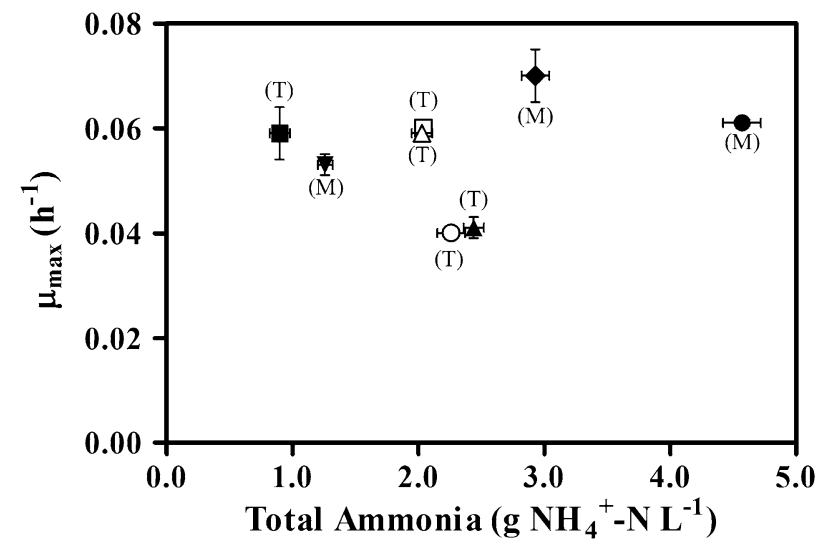
- Hashøj
- Hillerød
\ Lemvig
$\nabla$ Lundtofte
- Nysted
○ Snertinge
Studsgård

Fig. 1 Maximum specific growth rate $\left(\mu_{\max }\right)$ versus ammonia concentrations of the full-scale digesters. $\mathrm{M}$ and $\mathrm{T}$ represent mesophilic and thermophilic working conditions, respectively. Error bars denote standard deviation from the mean of triplicate measurements explained by the ammonia-VFA synergistic effect demonstrated previously by Lu et al. (2013). Furthermore, Angelidaki et al. (2005) have identified $1.5 \mathrm{~g} \mathrm{HAc} \mathrm{L}^{-1}$ as the VFA threshold for a healthy AD process in full-scale anaerobic digesters. The highest growth rates were observed in mesophilic and thermophilic digesters with initial VFA levels between 0.5 and $1.1 \mathrm{~g} \mathrm{HAc} \mathrm{L}^{-1}$, no matter of the ammonia levels (Fig. 1). Conversely, other studies have reported that VFA accumulation alleviates free ammonia toxicity in anaerobic digesters (Angelidaki et al. 1993; Hansen et al. 1998). Specifically, biomethanation process instability due to ammonia toxicity results in VFA accumulation, which leads to a $\mathrm{pH}$ decrease, alleviating consequently the free ammonia inhibition effect (Hejnfelt and Angelidaki 2009). This decrease in free ammonia could be an explanation for the stability of the process under increased VFA $\left(>1.5 \mathrm{~g} \mathrm{HAc} \mathrm{L}^{-1}\right)$ and
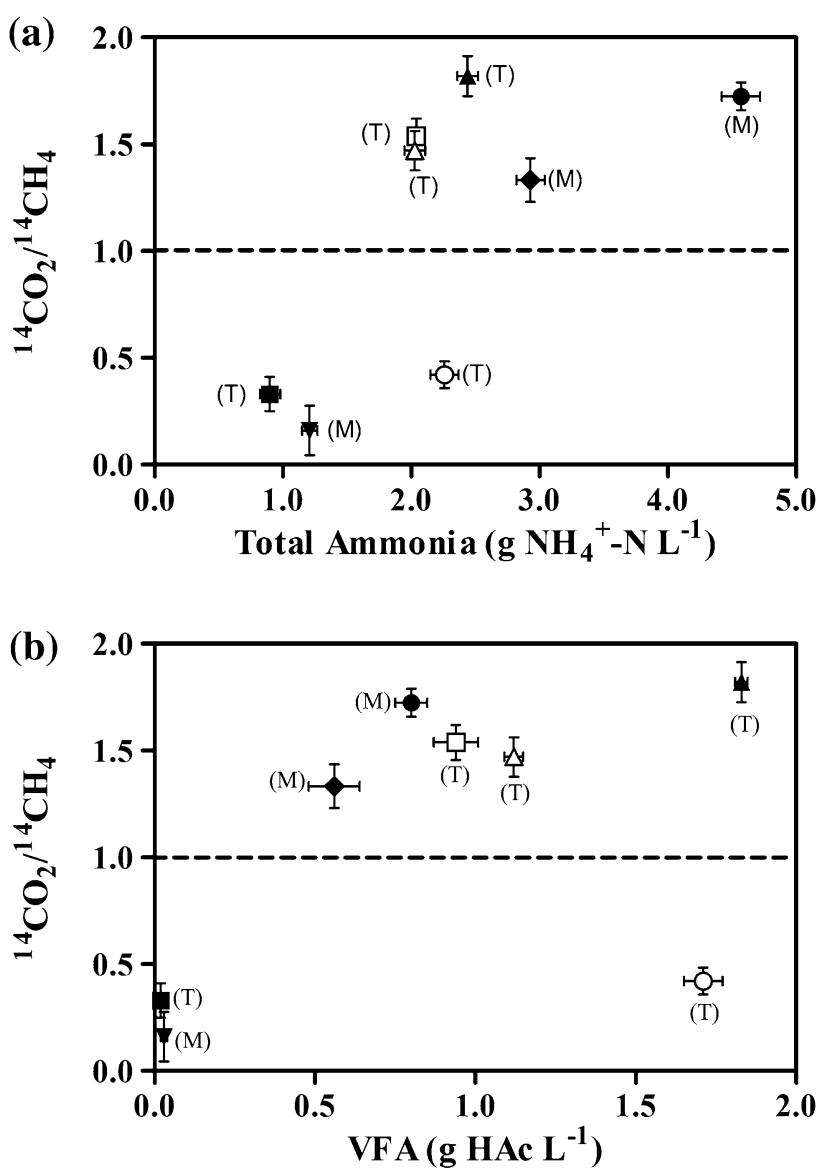
- Hashøj
- Hillerød
$\Delta \quad$ Lemvig
$\nabla$ Lundtofte
Nysted
o Snertinge
Studsgård $\Delta \quad$ Vegger

Fig. $2{ }^{14} \mathrm{CO}_{2} /{ }^{14} \mathrm{CH}_{4}$ ratio plotted with ammonia (2a) and VFA (2b) concentrations in full-scale digesters used in the experiments and the dominant methanogens. $\mathrm{M}$ and $\mathrm{T}$ represent mesophilic and thermophilic working conditions, respectively. Error bars denote standard deviation from the mean of triplicate measurements 
ammonia levels $\left(>2 \mathrm{~g} \mathrm{NH}_{4}^{+}-\mathrm{N} \mathrm{L}^{-1}\right)$, with lower but stable growth rates (Rajagopal et al. 2013). Although the ammonia-VFA synergistic effect in full-scale digesters has yet to be determined, our results suggest that when both ammonia and VFA levels are increased, AD process is affected.

Dominant acetate degradation pathway and methanogenic populations

At high ammonia $\left(>2.8 \mathrm{~g} \mathrm{NH}_{4}{ }^{+}-\mathrm{N} \mathrm{L}^{-1}\right)$ and high free ammonia $\left(>0.44 \mathrm{~g} \mathrm{NH}_{3}-\mathrm{N} \mathrm{L}^{-1}\right)$ levels, SAO-HM pathway was the dominant pathway (Fig. 2) mediated by hydrogenotrophic methanogens belonging to Methanomicrobiales spp. and Methanobacteriales spp., respectively (Fig. 3). The findings in this study clearly indicate that, in full-scale digesters, hydrogenotrophic methanogenic Archaea were tolerant to ammonia toxicity. These results are in agreement with previous laboratory-scale studies (Demirel and Scherer 2008; Ahring 1995). Hence, from data illustrated in Fig. 2 and Table 3, it can be concluded that the dominant methanogenic pathway and the abundance of the dominant methanogens are correlated with ammonia levels in the full-scale digesters.

An interesting finding was the identification of the nondominant Methanococcales spp. (Table 3) in a manure-fed digester (Nysted). This hydrogenotroph is not very common and usually appears in marine environments and wastewater-fed anaerobic digesters (Tabatabaei et al. 2010; Tumbula and Whitman 1999). Nevertheless, Methanococcales spp. have also been recently identified in continuous anaerobic digesters using fibrous biofilm carriers, treating mainly (75\%) fresh cow manure (Gong et al. 2011).

In anaerobic digesters, free ammonia levels increase concurrently with $\mathrm{pH}$ increase (Chen et al. 2008). Furthermore, $\mathrm{pH}$ values less than 6.8 and greater than 8.3 would cause process failure during AD (Banu et al. 2007). In the current study, isotopic analyses revealed that SAOHM pathway was dominant in all digesters with $\mathrm{pH}$ above 7.8 (Table 1; Fig. 3). High pH often coincides with high ammonia concentrations, which is consistent with the dominance of SAO-HM. Contrary to our results, Hao et al. (2012) reported that SAO-HM pathway was promoted by low $\mathrm{pH}(5.0-6.5)$ in laboratory-scale experiments. This inconsistency between the previously mentioned laboratory-scale results and the full-scale findings suggests that free ammonia (and not $\mathrm{pH}$ ) is one of the key environmental factors determining the methanogenic pathway in the complex anaerobic environments. Thus, based also on findings in previous studies (Fotidis et al. 2013a), it is possible to introduce SAO-HM pathway in a digester by controlling the ammonia levels as long as a "critical biomass" of ammonia-tolerant fast-growing methanogenic

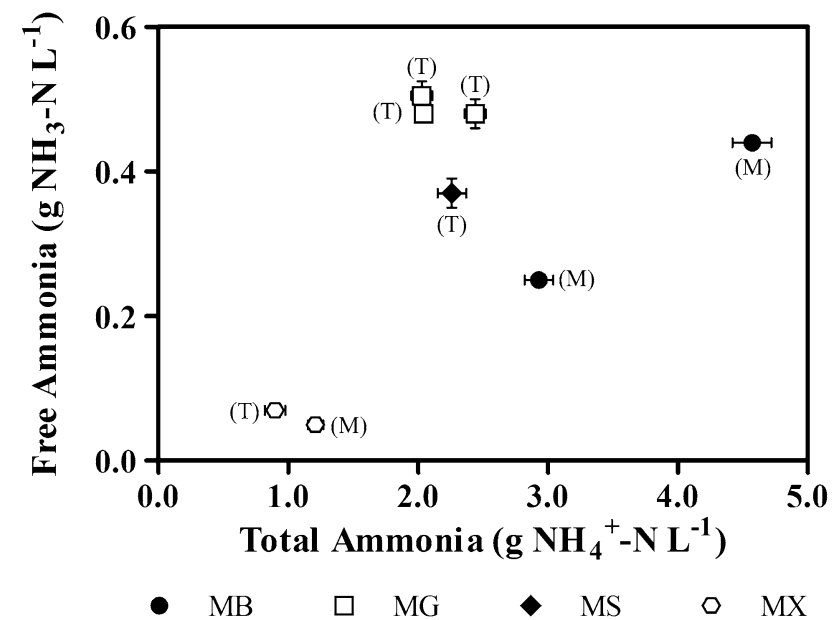

Fig. 3 Distribution of the dominant methanogens plotted with ammonia versus free ammonia concentrations in full-scale digester samples used in the experiments. $M B$ Methanobacteriales spp., $M G$ Methanomicrobiales spp., MS Methanosarcinaceae spp., MX Methanosaetaceae spp. $\mathrm{M}$ and $\mathrm{T}$ represent mesophilic and thermophilic working conditions, respectively. Error bars denote standard deviation from the mean of triplicate measurements

Table 3 Dominant and non-dominant methanogenic populations in the full-scale digesters

\begin{tabular}{|c|c|c|}
\hline Plant & Dominant $^{\mathrm{b}}$ & Non-dominant \\
\hline Nysted (M) & $\mathrm{MB}^{\mathrm{c}}$ & MS, MC \\
\hline Hashøj (M) & $\mathrm{MB}$ & MG, MS \\
\hline Lundtofte $(\mathrm{M})^{\mathrm{a}}$ & MX & MS \\
\hline Vegger $(\mathrm{T})$ & MG & $\mathrm{MB}, \mathrm{MS}$ \\
\hline Studsgård (T) & MG & $\mathrm{MS}, \mathrm{MB}$ \\
\hline Snertinge $(\mathrm{T})$ & MS & $\mathrm{MG}, \mathrm{MB}$ \\
\hline Lemvig (T) & MG & $\mathrm{MB}, \mathrm{MS}$ \\
\hline Hillerød $^{\mathrm{a}}(\mathrm{T})$ & MX & MS \\
\hline
\end{tabular}

${ }^{\mathrm{a}}$ Wastewater treatment plant

b Dominant methanogens: between 50 and $100 \%$ of the total number (positive for ARC915) of methanogenic cells; non-dominant methanogens: $1-49 \%$ of the total number of methanogenic cells

${ }^{c}$ MB Methanobacteriales spp., MC Methanococcales spp., $M G$ Methanomicrobiales spp., MS Methanosarcinaceae spp., MX Methanosaetaceae spp

(M) Mesophilic digester

(T) Thermophilic digester

consortium is present. If ammonia-tolerant consortia are not present, a technical approach to overcome ammonia inhibitions could be bioaugmentation (Schauer-Gimenez et al. 2010) of ammonia-tolerant methanogenic consortia in anaerobic digesters operating under high ammonia levels. Unfortunately, this has not been demonstrated yet. According to recent study (Westerholm et al. 2011), a bioaugmentation attempt in continuous laboratory-scale reactors was proven to be unsuccessful. Interestingly, in 
our recent study, we could successfully relieve ammonia inhibition by bioaugmentation approach (unpublished data).

At medium ammonia levels $\left(2.26 \mathrm{~g} \mathrm{NH}_{4}^{+}-\mathrm{N} \mathrm{L}^{-1}\right)$, ACM pathway was found to be dominant mediated by thermophilic Methanosarcinaceae spp. Acetoclastic Methanosarcinaceae spp. have been regarded as sensitive to ammonia in laboratory-scale experiments (Westerholm et al. 2011) but also capable of acclimatising to high ammonia and free ammonia levels (Jarrell et al. 1987). Nevertheless, the presence of Methanosarcinaceae spp. at high free ammonia levels (Fig. 2) indicates that acclimatisation of this methanogen to these free ammonia levels is also possible in full-scale digesters. At low ammonia concentrations $\left(<1.5 \mathrm{~g} \mathrm{NH}_{4}^{+}-\mathrm{N} \mathrm{L}^{-1}\right), \mathrm{ACM}$ was found to be the sole dominant pathway, mediated by Methanosaetaceae spp. (Fig. 3; Table 3). These findings are in agreement with previous researches, reporting that Methanosaetaceae spp. was the dominant methanogens in WWTP digesters operating under low ammonia and VFA levels (Karakashev et al. 2006). The current study was not aiming to perform a comparative analysis of the evolution of the dominant methanogens in the full-scale digesters through time. Nevertheless, the simple comparison of data derived from the same reactors seven years ago (Karakashev et al. 2005) and the current study indicates that the reactors with low $\left(<1.5 \mathrm{~g} \mathrm{NH}_{4}{ }^{+}-\mathrm{N} \mathrm{L}^{-1}\right)$ ammonia levels tend to have more stable dominant methanogenic communities compared to the reactors with medium and high $\left(>1.5 \mathrm{~g} \mathrm{NH}_{4}^{+}-\mathrm{N} \mathrm{L}^{-1}\right.$ ) ammonia levels. Undoubtedly, long-term monitoring of the microbial composition and the corresponding ammonia levels in the full-scale digesters is required before a link between the methanogens' population stability and ammonia levels is established.

\section{Conclusion}

This study investigated the effect of different ammonia levels on methanogenic pathways and methanogenic communities of eight full-scale anaerobic digesters. Ammonia and free ammonia levels were shown to have profound effect on the methanogenic pathway and methanogenic community profile of the full-scale anaerobic digesters tested. Furthermore, SAO-HM pathway was found to be dominant, mediated by Methanobacteriales spp. and Methanomicrobiales spp. at high ammonia $\left(>2.8 \mathrm{~g} \mathrm{NH}_{4}^{+}-\mathrm{N} \mathrm{L}^{-1}\right)$ and high free ammonia levels $\left(>0.44 \mathrm{~g} \mathrm{NH}_{3}-\mathrm{N} \mathrm{L}^{-1}\right.$ ), respectively. Results obtained pointed out that bioaugmentation of ammonia-tolerant methanogenic consortia in anaerobic digesters operating under high ammonia levels could be a technical approach to solve the ammonia toxicity problem.
Acknowledgments We thank Hector Garcia for technical assistance with the experiments and Mike Podevin for editing support. This work was supported by Energinet.dk under the project framework ForskEL "Innovative process for digesting high ammonia wastes" (programme no. 2010-10537) and by the Bioref-Øresund project under EU INTERREG IVA.

\section{References}

Ahring B (1995) Methanogenesis in thermophilic biogas reactors. Antonie van Leeuwenhoek Int J G 67:91-102

Angelidaki I, Ellegaard L, Ahring BK (1993) A mathematical model for dynamic simulation of anaerobic digestion of complex substrates: focusing on ammonia inhibition. Biotechnol Bioeng 42:159-166

Angelidaki I, Boe K, Ellegaard L (2005) Effect of operating conditions and reactor configuration on efficiency of full-scale biogas plants. Water Sci Technol 52:189-194

Angelidaki I, Karakashev D, Batstone DJ, Plugge CM, Stams AJM (2011) Biomethanation and its potential. In: Amy CR, Stephen WR (eds) Methods in enzymology, vol 494. Academic, New York, pp 327-351

APHA (2005) Standard methods for the examination of water and wastewater, 21st edn. American Public Health Association, Washington, DC

Banu JR, Kaliappan S, Yeom IT (2007) Treatment of domestic wastewater using upflow anaerobic sludge blanket reactor. Int J Environ Sci Technol 4:363-370

Chen Y, Cheng JJ, Creamer KS (2008) Inhibition of anaerobic digestion process: a review. Bioresour Technol 99:4044-4064

de Baere LA, Devocht M, Van Assche P, Verstraete W (1984) Influence of high $\mathrm{NaCl}$ and $\mathrm{NH}_{4} \mathrm{Cl}$ salt levels on methanogenic associations. Water Res 18:543-548

Demirel B, Scherer P (2008) The roles of acetotrophic and hydrogenotrophic methanogens during anaerobic conversion of biomass to methane: a review. Rev Environ Sci Biotechnol 7:173-190

Fotidis IA, Karakashev D, Angelidaki I (2013a) Bioaugmentation with an acetate-oxidising consortium as a tool to tackle ammonia inhibition of anaerobic digestion. Bioresour Technol 146:57-62

Fotidis IA, Karakashev D, Kotsopoulos TA, Martzopoulos GG, Angelidaki I (2013b) Effect of ammonium and acetate on methanogenic pathway and methanogenic community composition. FEMS Microbiol Ecol 83:38-48

Gong W-J, Liang H, Li W-Z, Wang Z-Z (2011) Selection and evaluation of biofilm carrier in anaerobic digestion treatment of cattle manure. Energy 36:3572-3578

Gray N, Sherry A, Larter S, Erdmann M, Leyris J, Liengen T, Beeder J, Head I (2009) Biogenic methane production in formation waters from a large gas field in the North Sea. Extremophiles 13:511-519

Hafner SD, Bisogni JJ, Jewell WJ (2006) Measurement of un-ionized ammonia in complex mixtures. Environ Sci Technol 40:1597-1602

Hansen KH, Angelidaki I, Ahring BK (1998) Anaerobic digestion of swine manure: inhibition by ammonia. Water Res 32:5-12

Hao L-P, Lü F, Li L, Shao L-M, He P-J (2012) Shift of pathways during initiation of thermophilic methanogenesis at different initial pH. Bioresour Technol 126:418-424

Hejnfelt A, Angelidaki I (2009) Anaerobic digestion of slaughterhouse by-products. Biomass Bioenerg 33:1046-1054

Hugenholtz P (2002) Design and evaluation of 16S rRNA-targeted oligonucleotide probes for fluorescence in situ hybridization. In: Aquino de Muro M, Rapley R (eds) Gene probes: principles and protocols. Humana Press, Totowa, pp 29-42 
Jarrell KF, Saulnier M, Ley A (1987) Inhibition of methanogenesis in pure cultures by ammonia, fatty acids, and heavy metals, and protection against heavy metal toxicity by sewage sludge. Can J Microbiol 33:551-554

Karakashev D, Batstone DJ, Angelidaki I (2005) Influence of environmental conditions on methanogenic compositions in anaerobic biogas reactors. Appl Environ Microbiol 71:331-338

Karakashev D, Batstone DJ, Trably E, Angelidaki I (2006) Acetate oxidation is the dominant methanogenic pathway from acetate in the absence of methanosaetaceae. Appl Environ Microbiol 72:5138-5141

Kayhanian M (1994) Performance of a high-solids anaerobic digestion process under various ammonia concentrations. J Chem Technol Biotechnol 59:349-352

Koster IW, Koomen E (1988) Ammonia inhibition of the maximum growth rate $\left(\mu_{\mathrm{m}}\right)$ of hydrogenotrophic methanogens at various $\mathrm{pH}$-levels and temperatures. Appl Microbiol Biotechnol 28:500-505

Kotsopoulos TA, Fotidis IA, Tsolakis N, Martzopoulos GG (2009) Biohydrogen production from pig slurry in a CSTR reactor system with mixed cultures under hyper-thermophilic temperature $\left(70^{\circ} \mathrm{C}\right)$. Biomass Bioenerg 33:1168-1174

Kougias PG, Fotidis IA, Zaganas ID, Kotsopoulos TA, Martzopoulos GG (2013) Zeolite and swine inoculum effect on poultry manure biomethanation. Int Agrophys 27:169-173

Lu F, Hao L, Guan D, Qi Y, Shao L, He P (2013) Synergetic stress of acids and ammonium on the shift in the methanogenic pathways during thermophilic anaerobic digestion of organics. Water Res 47:2297-2306

Minale M, Worku T (2013) Anaerobic co-digestion of sanitary wastewater and kitchen solid waste for biogas and fertilizer production under ambient temperature: waste generated from condominium house. Int J Environ Sci Technol. doi: 10.1007/ s13762-013-0255-7

Nakashimada Y, Ohshima Y, Minami H, Yabu H, Namba Y, Nishio N (2008) Ammonia-methane two-stage anaerobic digestion of dehydrated waste-activated sludge. Appl Microbiol Biotechnol 79:1061-1069

Nielsen HB, Angelidaki I (2008a) Codigestion of manure and industrial organic waste at centralized biogas plants: process imbalances and limitations. Water Sci Technol 58:1521-1528

Nielsen HB, Angelidaki I (2008b) Strategies for optimizing recovery of the biogas process following ammonia inhibition. Bioresour Technol 99:7995-8001
Rajagopal R, Massé DI, Singh G (2013) A critical review on inhibition of anaerobic digestion process by excess ammonia. Bioresour Technol 0. (in press) doi:10.1016/j.biortech.2013.06. 030

Raskin L, Stromley JM, Rittmann BE, Stahl DA (1994) Groupspecific 16S rRNA hybridization probes to describe natural communities of methanogens. Appl Environ Microbiol 60:1232-1240

Sarmiento FB, Leigh JA, Whitman WB (2011) Genetic systems for hydrogenotrophic methanogens. In: Amy CR, Stephen WR (eds) Methods in enzymology, vol 494. Academic, New York, pp 43-73. doi:10.1016/B978-0-12-385112-3.00003-2

Schauer-Gimenez AE, Zitomer DH, Maki JS, Struble CA (2010) Bioaugmentation for improved recovery of anaerobic digesters after toxicant exposure. Water Res 44:3555-3564

Sekiguchi Y, Kamagata Y, Nakamura K, Ohashi A, Harada H (1999) Fluorescence in situ hybridization using 16S rRNA-targeted oligonucleotides reveals localization of methanogens and selected uncultured bacteria in mesophilic and thermophilic sludge granules. Appl Environ Microbiol 65:1280-1288

Shima S, Hérault DA, Berkessel A, Thauer RK (1998) Activation and thermostabilization effects of cyclic 2,3-diphosphoglycerate on enzymes from the hyperthermophilic Methanopyrus kandleri. Arch Microbiol 170:469-472

Stahl DA, Amann R (1991) Development and application of nucleic acid probes. In: Stackebrandt E, Goodfellow M (eds) Nucleic acid techniques in bacterial systematics. Wiley, Chichester, United Kingdom, pp 205-248

Stams AJM, De Bok FAM, Plugge CM, Van Eekert MHA, Dolfing J, Schraa G (2006) Exocellular electron transfer in anaerobic microbial communities. Environ Microbiol 8:371-382

Tabatabaei M, Rahim RA, Abdullah N, Wright A-DG, Shirai Y, Sakai K, Sulaiman A, Hassan MA (2010) Importance of the methanogenic archaea populations in anaerobic wastewater treatments. Process Biochem 45:1214-1225

Tumbula DL, Whitman WB (1999) Genetics of Methanococcus: possibilities for functional genomics in Archaea. Mol Microbiol 33:1-7

Westerholm M, Dolfing J, Sherry A, Gray ND, Head IM, Schnürer A (2011) Quantification of syntrophic acetate-oxidizing microbial communities in biogas processes. Environ Microbiol Rep 3:500-505

Yenigün O, Demirel B (2013) Ammonia inhibition in anaerobic digestion: a review. Process Biochem 48:901-911 